\title{
BIODIVERSITY IN RIFFLES AND POOLS OF THE MARDI AND THE VIJAYPUR STREAMS, POKHARA, NEPAL: BENTHIC MACROINVERTEBRATE COMMUNITIES
}

\author{
Kishor K. Pokharel ${ }^{*}$
}

\begin{abstract}
Macroinvertebrate communities from September 2003 to August 2004 were studied in riffles and pools of the Mardi and the Vijayapur streams, Pokhara, Nepal. A total of 47 genera (32 from the riffles and 34 from the pools) belonging to 38 families and 12 orders were recorded. The generic richness was lower (30 genera) in the Vijaypur stream than in the Mardi stream (38 genera).

Ephemeropteran, dipteran, and trichopteran were found predominant orders comprising 11, 8 and 8 genera respectively. Heptagenids, baetids and leptophlebids; chironomids, ceratopagonids and tipulids and hydropsychids, psychomyids and polycentropodids were dominant sub-groups/families among ephemeropterans, dipterans and trichopterans respectively. The dominant genera were, Heptagenia, Rhithrogena and Baetis; Tendipes, Culicoids and Simulium; Hydropsyche and Psychomyia; Psephenus and Heterlimnius; Octogomphus and Argia and Planaria among ephemeropterans, dipterans, trichopterans, plecopterans, coleopherans, odonates and tricladids respectively. The taxa occurred at both streams and sub-habitats were, Ephemera, Heptagenia, Rhithrogena, Ecdyonurus, Ephemerella, Baetis, Leptophlebia, Caenis; Tendipes, Culicoides, Simulium; Hydropsyche, Psychomyia, Psephenus, Heterlimnius and Planaria. Those occurred only in the Mardi stream (Site 1) were Habrophlebia, Siphlonurus; Glossosoma, Hydroptila, Leptocerus; Nemoura, Protonemura, Octogomphus, Argia and Gyraulus convexiculus, whereas, only in the Vijaypur stream (Site 2) were Centroptylum; Antocha, Psychoda, Tabanus, Agapetus and Ectopria. The lower taxa richness at the site having urban influence reflects perturbation of riverine environment due to urbanization and needs measures to control further deterioration.
\end{abstract}

Key words: Macroinvertebrates, stream bio-diversity, distribution, riffles, pools.

\section{INTRODUCTION}

The invertebrates living on, the bottom of the water body playing a vital role in the aquatic ecosystem are macro-invertebrates or macro-zoobenthos. Several investigators have pointed out that many aquatic insects were evolved in cool lotic waterbodies prior to spreading to warmer riverine and lacustrine environments (Hynes, 1970; Ward, 1992 and Wetzel, 2001). Some of these biota form the food of fishes, while others act as predators on young fishes and other

Mr. Pokhrel is an Associate Professor, Department of Zoology, Prithvi Narayan Campus, T.U., Pokhara, Nepal. 


\section{BIODIVERSITY IN RIFFLES AND POOLS OF THE...}

aquatic fauna. Many researchers have focused their attention on the role of these bottom dwelling invertebrates as fish food, being the most diverse fauna of running waters (Mohan and Bisht 1991; Allan, 1995), some worked on their abundance for measuring diversity indices as biomonitors and indicators of water quality and environmental conditions of lotic waterbodies (Norris and Norris 1995, Dudgeon 1999), some others incorporated them into general models of structure and function of stream ecosystem (Fisher and Likens, 1973, Cummins and Meritt 1996) and recent works on riverine macro-invertebrate assemblage have concentrated on variations in population and community dynamics and secondary production in response to environmental variables (Minshall et al. 1985, Cummins 1992, Sharma et al. 2004).

Studies on macroinvertebrate fauna have been done by aquatic biologists (Das, 1971; Walsh et al., 2001). Some works have been performed in Nepalese waterbodies (Sharma, 1975; Yadav and Rajbhandari 1982; Vaidya et al., 1988; Ormerod et al., 1994; Brewin et al., 2000; Sharma et al., 2006 etc.). However, those of the Mardi stream and Vijaypur stream in Pokhara valley probably have not yet been studied. The Mardi, a snow-fed high altitude stream flowing through the base of Himalayas and the Vijayapur, a spring-fed mid-hill stream flowing through the base of Mahabharat hills in Pokhara valley, Nepal represent typical Himalayan lotic ecosystem with unique physio-hydrological features such as, high velocity, low or moderate temperature, unstable river-bed substrata etc. Considering their importance in aquatic ecosystem and lack of literature, present work aims to explore the macro-invertebrate fauna of these streams.

\section{STUDY AREA}

Pokhara, "a beautiful valley of nature's paradise" in centro-western Nepal Himalaya, has many fascinating waterbodies-river, streams, creeks, lakes and ponds. It covers an area of about 200 sq. km. extending between $25^{\circ} 07^{\prime}$ and $28^{\circ} 10^{\prime} \mathrm{N}$ latitude and $83^{\circ} 50^{\prime}$ and $84^{\circ} 50^{\prime} \mathrm{E}$ longitude and lies $800 \mathrm{~m}$ asl (Tripathi 1984-85). The lotic waterbodies flowing through the valley are the Seti Gandaki river and its tributaries. The Mardi khola/stream and the Vijayapur khola/stream are its major tributaries (Fig. 1). Two sites were selected on these streams which are as follows:

\section{Site 1. MARDI KHOLA/STREAM}

The first site was situated near the confluence of the Mardi khola with the Seti Gandaki river near Mardi, about $13 \mathrm{~km}$. upstream from the densely populated Pokhara city area and about $25 \mathrm{~km}$ upstream from Site 2. It had erosion-sensitive banks on both the sides and the watershed area had forests, agricultural fields and villages. The stream-bed had less sand and gravels but with more stones and boulders.

\section{SITE 2. VIJAYPUR KHOLA/STREAM}

The second site was on the Vijaypur khola/stream near its confluence with the Seti Gandaki river, located about $12 \mathrm{~km}$. downstream from the densly populated Pokhara city area and about $25 \mathrm{~km}$ downstream from the first site. The 
banks on both the sides were found severely eroded. The watershed area had agricultural fields, poultry farms and villages. The surface run-off from the catchment area as well as the human activities such as, bathing, washing of various items including the vehicles releasing chemical substances into the water. The stream-bed was covered with pebbles, stones and boulders with less sand.

\section{MATERIALS AND METHODS}

Present work was performed from September 2003 to August 2004. The macroinvertebrates were sampled using Surber sampler $\left(0.093 \mathrm{~m}^{2}\right)$. Five replicate samples were taken monthly from riffles and pools at each site. The samples were screened using the sieve $(0.5 \mathrm{~mm}$. mesh net), kept in polythene bags, preserved in $4 \%$ formalin and carried to the laboratory for further works. The samples were sorted group-wise and kept in vials containing 70\% alcohol. The samples were identified to the lowest possible taxonomic level using taxonomic monographs/books (Edmondson, 1959; Needham and Needham, 1962; Mellanby, 1963; Pennak, 1978; Tonapi, 1980; Dudgeon, 1999 and Nesemann et al., 2007).

\section{RESULTS}

Altogether 47 genera belonging to 38 families and 12 orders, viz., ephemeroptera, diptera, trichoptera, plecoptera, coleoptera, odonata, hemiptera, megaloptera, tricladida, plesiopora, rhynchobdellida and pulmonata were recorded during the study period (Table 1), comprising 32 genera from riffles and 34 genera from pools.

Ephemeropterans, dipterans and trichopterans comprising 11, 8 and 8 genera respectively were predominant groups/orders among the macroinvertebrates followed by odonates, plecopterans, coleopterans, pulmonates, hemipterans, megalopterans, tricladids, plesioporans, and rhynchobdellids comprising 5, 4, 4, 2, 1, 1, 1, 1 and 1 general respectively. Among ephemeropterans, the heptagenids, baetids and leptophlebids were found to be the dominant sub-groups/families comprising 3,2 and 2 genera followed by ephemerids, ephemerellids, caenids and siphlonurids having representation of single genus each. Similarly, among dipterans, chironomids, ceratopogonids, tipulids, psychodids, tabanids, culicids, simulids and athericids were observed to have equal representation of single genus. Likewise, among trichopterans, hydropsychids, psychomyids, polycentropodids, hydroptilids, leptocerids and limnephilids were found to have single genus each, while glossosomatids were having representation of 2 genera. The dominant genera were, Heptagenia, Rhithrogena, Baetis, Leptophlebia and Ephemera; Tendipes, Culicoides and Simulium; Hydropsyche and Psychomyia; Perla, Nemouria, and Protonemura; Psephenus and Heterlimnius; Octogomphus and Argia and Planaria among ephemeropterans, dipterans, trichopterans, plecopterans, coleopterans, odonates and tricladids respectively.

The genera recorded from both the sites and sub-habitats (riffles and pools) were Ephemera, Heptagenia, Rhithrogena, Ecdyonurus, Ephemerella, Baetis, Leptophlebia and Caenis; Tendipes, Culicoides and Simulium; Hydropsyche and Psychomyia; Pesphenus and Heterlimnius and Planaria among 


\section{BIODIVERSITY IN RIFFLES AND POOLS OF THE ...}

ephemeropterans, dipterans, trichopterans, coleopterans, and tricladids respectively. Whereas, the genera recorded from both the sub-habitats (riffles and pools) at Site 1 were, Habrophlebia and Siphlonurus; Glossosoma, Hydroptila and Leptocerus; Perla, Nemouria and Protonemura; Octogomphus and Argia and Gyraulus among ephemeropterans, trichopterans, plecoterans, coleopterans, odonates and hygrophilids respectively and those recorded from both sub-habitats at Site 2 were, Centroptylum; Antocha, Psychoda and Tabanus; Agapetus; Ectopria and Corydalus among ephemeropterans, dipterans, trichopterans, coleopterans and megalopterans respectively.

The genera recorded only from the pools at both the sites were, Ophiogomphus and Tubifex among odonates and plesioporans respectively. Those recorded only from the riffles at Site 1 were, Polycentropus and Limnephilus; Isoperla and Corydalis among trichopterans, plecopterans, and megalopterans respectively and those only from the pools were Atherix; Dytiscus; Dromogomphus and Sympetrum and Corixa among dipterans, coleopterans, odonates and hemipterans respectively. Whereas, those recorded only from the riffle at Site 2 was Perla among plecopterans and only from pool were Hemiclepsis and Lymnaea among rhynchobdellids and respectively.

The generic richness being lower (30 genera) at Site 2 (Vijaypur stream) than at Site 1 (Mardi stream) (38 genera) was most probably due to urban influence upon the aquatic ecosystem. The prominent human activities observed at the study sites were extraction of sand, stones, gravels, and breaking of boulders from the river-bed and banks, movement of heavy vehicles for transportation of extracted materials, electro-fishing, release of toxic substances from the agricultural fields (using chemical fertilizers and pesticides) and human settlements in the catchment areas and direct disposal of wastes into the stream water. The above activities most probably had influence on the abiotic and biotic components of the stream ecosystem particularly at Site 2, having lower generic richness, which indicates the perturbation of the aquatic environment due to urbanization and needs measures to control further deterioration.

\section{DISCUSSION}

Generally the ephemeropterans were found to be the dominant group among the macro-invertebrates followed by trichoptera, plecoptera, diptera, coleopteran, odonata, hemiptera, oligochaeta, megaloptera etc. in hill-streams having natural environmental conditions. The dominant representative families of insects reported were, baetidae, ephemeridae and ephemerellidae; chironomidae, ceratopogonidae and simuliidae; hydropsychidae and limnephilidae among ephemeropterans, dipterans and trichopterans. In mid-land streams, the aquatic insects, their larvae or nymphs constituted more than $85 \%$ of which ephemeropterans, trichopterans, dipterans and plecopterans contributed major part of the total faunal composition (Ormerod et al., 1994; Sharma et al., 2004). Similar composition and dominance of macroinvertebrates were observed in the present study, which could be attributed to the complex physiohydrological characteristics and zoogeographical factors. 
There was increasing trend of taxa richness at upstream to downstream sites, maximum richness at the transition between montane and valley sites, a significant decrease at the valley sites and decline of habitat stability and diversity at the urban sites (Useeglio-P and Beisel 2002; Sharma et al., 2004). In the present study, the generic richness was lower at the site having urban influence, which could be due to the diverse physiography along-with various abiotic and biotic factors including the human activities.

The riffle dominant taxa (ephemeroptera, trichoptera and plecoptera) were having higher taxa richness at riffle stations in comparison to the pool stations, where pool dominant taxa (diptera, odonata, coleoptera and oligochaeta) counted higher (Sunder 1997; Carter and Fend 2001). Similarly taxa richness was observed in the present work, which could be attributed to the heterogeneity of substrata, velocity of water etc.

\section{ACKNOWLEDGEMENTS}

I am obliged to Prof. T.C. Majupuria, formerly Central Department of Zoology and Prof. K. Basnet, Central Department of Zoology, Tribhuvan University (T.U.) for valuable suggestions and encouragement. I am grateful to Institute of Science and Technology (IOST), T.U. for providing research grant to conduct the study. I am thankful to Associate Prof. P.J. Shah, then Head and to Associate Prof. R.G. Dhawajoo, Head, Department of Zoology, Prithvi Narayan Campus (PNC), Pokhara for providing the necessary laboratory facilities. Similarly, I am grateful to Prof. S.J. Ormerod, Catchment Research Group, Cardiff University, UK; H. Nesemann, Associate Prof. S.N. Khanal and Assoociate Prof. S. Sharma, Department of Biological Sciences, Kathmandu University (KU); Prof. R.C. Sharma and Miss Punam, H.N.B. Garhwal University, Tehri Garhwal, India for their valuable suggestions, appreciation and help in identification of macro-invertebrates.

Thanks are also due to Mr. B.R. Pahari and S. Paudel, Laboratory staff, PNC and Mr. N.P. Adhikari, Bhalam, Kaski for assistance in the laboratory and field works.

\section{WORKS CITED}

Allan, J.D. (1995). Stream Ecology-Structure and Function of Running Waters. Kluwer Academic Publishers, Dordrecht, The Netherlands, p. 388.

Brewin, P.A., S.T. Buckton and S.J. Ormerod. (2000). The seasonal dynamics and persistence of stream macroinvertebrates in Nepal : Do monsoon floods represent disturbance? Freshwater Biology, 44:581-594.

Carter, J.L. and S.V. Fend. (2001). Inter-annual changes in the benthic community structure of riffles and pools in reaches of contrasting gradient. Hydrobiologia, 459:187-200.

Cummins, K.W. (1992). Invertebrates. pp. 234-250 in P. Calow and G.E. Petts (editors). The Rivers Handbook. I. Hydrological and Ecological Principles. Blackwell Scientific Publishers, Oxford. 
Das, S.M. (1971). Teaching and research in limnology in India. Proceedings of Symposium, UGC NCSE, Banglore, p. 72.

Dudgeon, D. (1999). Tropical Asian Streams. Hong Kong: Hong Kong University Press.

Edmondson, W.T. (1959). Fresh Water Biology. New York: John Wiley and Sons, Inc.

Hynes, H.B.N. (1970). The Ecology of Running Waters. Liverpool: .Liverpool University Press.

Mellanby, H. (1963). Animal Life in Fresh Water. UK: Methuen and Co. Limited, New Fetter Lane.

Minshall, G.W., K.W. Cummins, R.C. Peterson, C.E. Cushing, D.A. Bruns, J.R. Sedell and R.L. Vannote. (1985). Developments in stream ecosystem theory. Canadian Journal of Fisheries and Aquatic Sciences. 42:1045-1055.

Mohan, M. and R.S. Bisht. (1991). Taxo-ecology of aquatic entomo fauna in freshwater ecosystem with special reference to River Bhagirathi and Bhilangana in Garhwal Himalaya. pp. 251-265 in S.D. Bhatt and R.K. Pande (editors). Ecology of the Mountain Waters. New Delhi: Ashish Publishing House, India.

Needham, J.G. and P.F. Needham. (1962). A Guide to the Study of Fresh-Water Biology. Holden-Day Inc., San Francisco.

Nesemann, H., S. Sharma, G.Sharma, S.N. Khanal, B. Pradhan, D.N. Shah and R.D. Tachamo. (2007). Aquatic Invertebrates of the Ganga River System. H. Nesemann, Kathmandu University, Dhulikhel, Nepal.

Norris, R.H. and K.R. Norris. (1995). The need for biological assessment of water quality : Australian perspective. Australian Journal of Ecology. 2: 1-6.

Ormerod, S.J., S.D. Rundle, S.M. Wilkinson, G.P. Daly, K.M. Dale and I. Juttner. (1994). Altitudinal trends in the diatoms, bryophytes, macroinvertebrates and fish of a Nepalese river system. Freshwater Biology, 32(2): 309-322.

Pennak, R.W. (1978). Freshwater Invertebrates of the United States. Second Edition. Wiley-Interscience Publishers, New York, p. 803.

Sharma, K.C. (1975). A note on the odonate collections in the Entomology Division of the Department of Agriculture, Nepal. Odonatologica, 4: 89-93.

Sharma, R.C., G. Bhanot and D. Singh. (2004). Aquatic macro-invertebrate diversity in Nanda Devi Bioshpere Reserve, India. The Environmentalist, 24: $211-221$.

Sharma, S., M. Allen, A. courage, H. Hall, S. Koirala, S. Oliver and B. Zimmerman. (2006). Assessing water quality for ecosystem health of the Babai river in Royal Bardia National Park, Nepal. Proceedings of Fourth National Conference on Science and Technology. Nepal Academy of Science and Technology (NAST), Lalitpur, Nepal, pp. 2197-2206. 
Sunder, S. (1997). Biotic communities of a Kumaon Himalayan river- The Gaula1. Macrobenthic invertebrates. Proceedings of the National Academy of Sciences India, Section B(Biological Sciences), 64(2): 157-168.

Tonapi, G.T. (1980). Fresh Water Animals of India. Oxford and IBH Publishing Co., New Delhi, India, p. 341.

Tripathi, M.P. (1984-85). Ecology of Pokhara valley. pp. 438-452 in T.C. Majupuria (editor). Nepal-Nature's Paradise. White Lotus Co., Bangkok, Thailand.

Useeglio-Polatera, P. and J.N. Beisel. (2002). Longitudinal changes in macroinvertebrate assemblages in the Meuse river: Anthropogenic effects versus natural change. River Research and Applications, 18(2): 197-211.

Vaidya, K., A.P. Gorkhali, S. Khanal and T.M. Pradhanga. (1988). Water pollution in the Bagmati river. Proceedings of Seminar on Environmental Issues of Pashupati Area: Identification and Control Measures. Royal Nepal Academy of Science and Technology (RONAST), Kathmandu, Nepal, pp. 158-180.

Walsh, C.J., A.K. Sharp, P.F. Breen and J.A. Sonneman (2001). Effects of urbanization on streams of the Melbourn region, Victoria, Australia. I. Benthic macroinvertebrate communities. Freshwater Biology, 46: 535-551.

Ward, J.V. (1992). Aquatic Insect Ecology. I. Biology and Habitat. John Wiley and Sons, New York, USA, p. 438.

Wetzel, R.G. (2001). Limnology. Third Edition. Academic Press, San Diego, California, USA. p. 1006.

Yadav, U.K.R. and B.S. Rajbhandari (1982). Studies on the benthic macro-fauna of Bansbari khola and Dhobi khola in Kathmandu, Nepal. Journal of Institute of Science, 5:133-155. 
Table 1: Diversity of macroinvertebrates in the Mardi and the Vijaypur streams.

\begin{tabular}{|c|c|c|c|c|}
\hline S.N. & Taxa & Station & $\begin{array}{c}\text { Distribution } \\
1\end{array}$ & $\begin{array}{c}\text { Sites } \\
2\end{array}$ \\
\hline & $\begin{array}{l}\text { Order: Ephemeroptera } \\
\text { Family: Ephemeridae }\end{array}$ & & & \\
\hline 01. & Ephemera Linnaeus & $\mathrm{R}$ & + & + \\
\hline & Family: Heptageniidae & $\mathrm{P}$ & + & + \\
\hline 02. & Heptagenia Walsh & $\begin{array}{l}\mathrm{R} \\
\mathrm{P}\end{array}$ & $\begin{array}{l}+ \\
+\end{array}$ & $\begin{array}{l}+ \\
+\end{array}$ \\
\hline 03. & Rhithrogena Eaton & $\begin{array}{l}\mathrm{R} \\
\mathrm{P}\end{array}$ & $\begin{array}{l}+ \\
+\end{array}$ & $\begin{array}{l}+ \\
+\end{array}$ \\
\hline 04. & Ecdyonurus sp. & $\begin{array}{l}\mathrm{R} \\
\mathrm{P}\end{array}$ & $\begin{array}{l}+ \\
+\end{array}$ & $\begin{array}{l}+ \\
+\end{array}$ \\
\hline 05 . & $\begin{array}{l}\text { Family: Ephemerellidae } \\
\text { Ephemerella Walsh }\end{array}$ & $\begin{array}{l}\mathrm{R} \\
\mathrm{P}\end{array}$ & $\begin{array}{l}+ \\
+\end{array}$ & $\begin{array}{l}+ \\
+\end{array}$ \\
\hline & Family: Baetidae & & & \\
\hline 06. & Baetis Leach & $\begin{array}{l}\mathrm{R} \\
\mathrm{P}\end{array}$ & $\begin{array}{l}+ \\
+\end{array}$ & $\begin{array}{l}+ \\
+\end{array}$ \\
\hline 07. & Centroptylum Westwood & $\begin{array}{l}\mathrm{R} \\
\mathrm{P}\end{array}$ & - & $\begin{array}{l}+ \\
+\end{array}$ \\
\hline 08. & $\begin{array}{l}\text { Family: Leptophlebidae } \\
\text { Leptophlebia Eaton }\end{array}$ & $\begin{array}{l}\mathrm{R} \\
\mathrm{P}\end{array}$ & $\begin{array}{l}+ \\
+\end{array}$ & $\begin{array}{l}+ \\
+\end{array}$ \\
\hline 09. & Habrophlebia Stephens & $\begin{array}{l}\mathrm{R} \\
\mathrm{P}\end{array}$ & $\begin{array}{l}+ \\
+\end{array}$ & - \\
\hline 10. & $\begin{array}{l}\text { Family: Caenidae } \\
\text { Caenis Eaton }\end{array}$ & $\begin{array}{l}\mathrm{R} \\
\mathrm{P}\end{array}$ & $\begin{array}{l}+ \\
+\end{array}$ & $\begin{array}{l}+ \\
+\end{array}$ \\
\hline 11. & $\begin{array}{l}\text { Family: Siphlonuridae } \\
\text { Siphlonurus Eaton }\end{array}$ & $\begin{array}{l}\mathrm{R} \\
\mathrm{P}\end{array}$ & $\begin{array}{l}+ \\
+\end{array}$ & $\begin{array}{l}- \\
-\end{array}$ \\
\hline & $\begin{array}{l}\text { Order: Diptera } \\
\text { Family: Chironomidae }\end{array}$ & & & \\
\hline 12. & Tendipes Meigen & $\begin{array}{l}\mathrm{R} \\
\mathrm{P}\end{array}$ & $\begin{array}{l}+ \\
+\end{array}$ & $\begin{array}{l}+ \\
+\end{array}$ \\
\hline & Family: Ceratopogonidae & & & \\
\hline 13. & Culicoides Latreille & $\begin{array}{l}\mathrm{R} \\
\mathrm{P}\end{array}$ & $\begin{array}{l}+ \\
+\end{array}$ & $\begin{array}{l}+ \\
+\end{array}$ \\
\hline 14. & Antocha Osten Sacken & $\begin{array}{l}\mathrm{R} \\
\mathrm{P}\end{array}$ & - & $\begin{array}{l}+ \\
+\end{array}$ \\
\hline
\end{tabular}

Family: Psychodidae 


\begin{tabular}{|c|c|c|c|c|}
\hline S.N. & Taxa & Station & $\begin{array}{c}\text { Distribution } \\
1 \\
\end{array}$ & $\begin{array}{c}\text { Sites } \\
2\end{array}$ \\
\hline & Family: Tipulidae & & & \\
\hline \multirow[t]{3}{*}{15.} & Psychoda Latreille & $\mathrm{R}$ & - & + \\
\hline & & $\mathrm{P}$ & - & + \\
\hline & Family: Tabanidae & & & \\
\hline \multirow[t]{3}{*}{16.} & Tabanus Linnaeus & $\mathrm{R}$ & - & + \\
\hline & & $\mathrm{P}$ & - & + \\
\hline & Family: Culicidae & & & \\
\hline \multirow[t]{3}{*}{17.} & Culex Linnaeus & $\mathrm{R}$ & - & - \\
\hline & & $\mathrm{P}$ & - & + \\
\hline & Family: Simuliidae & & & \\
\hline \multirow[t]{2}{*}{18.} & Simulium Hagen & $\mathrm{R}$ & + & + \\
\hline & & $\mathrm{P}$ & + & + \\
\hline \multicolumn{5}{|c|}{ Family: Leptidae (Athericidae) } \\
\hline \multirow[t]{4}{*}{19.} & Atherix Meigen & $\mathrm{R}$ & - & - \\
\hline & & $\mathrm{P}$ & + & - \\
\hline & Order: Trichoptera & & & \\
\hline & Family: Hydropsychidae & & & \\
\hline \multirow[t]{3}{*}{20.} & Hydropsyche Pictet & $\mathrm{R}$ & + & + \\
\hline & & $\mathrm{P}$ & + & + \\
\hline & Family: Psychomyidae & & & \\
\hline \multirow[t]{3}{*}{21.} & Psychomyia Pictet & $\mathrm{R}$ & + & + \\
\hline & & $\mathrm{P}$ & + & + \\
\hline & Family: Glossosomatidae & & & \\
\hline \multirow[t]{2}{*}{22.} & Glossosoma Curtis & $\mathrm{R}$ & + & - \\
\hline & & $\mathrm{P}$ & + & + \\
\hline \multirow[t]{3}{*}{23.} & Agapetus Curtis & $\mathrm{R}$ & - & + \\
\hline & & $\mathrm{P}$ & - & + \\
\hline & Family: Polycentropodidae & & & \\
\hline \multirow[t]{3}{*}{24.} & Polycentropus Curtis & $\mathrm{R}$ & + & - \\
\hline & & $\mathrm{P}$ & - & - \\
\hline & Family: Hydroptilidae & & & \\
\hline \multirow[t]{3}{*}{25.} & Hydroptila Dalman & $\mathrm{R}$ & + & - \\
\hline & & $\mathrm{P}$ & + & - \\
\hline & Family: Leptoceridae & & & \\
\hline \multirow[t]{2}{*}{26.} & Leptocerus Leach & $\mathrm{R}$ & + & - \\
\hline & & $\mathrm{P}$ & + & - \\
\hline \multirow[t]{4}{*}{27.} & Limnephilus Leach & $\mathrm{R}$ & + & - \\
\hline & & $\mathrm{P}$ & - & - \\
\hline & Order: Plecoptera & & & \\
\hline & Family: Perlidae & & & \\
\hline \multirow[t]{3}{*}{28.} & Neoperla Needham & $\mathrm{R}$ & + & + \\
\hline & & $\mathrm{P}$ & + & - \\
\hline & Family: Perlodidae & & & \\
\hline \multirow[t]{2}{*}{29.} & Isoperla Banks & $\mathrm{R}$ & + & - \\
\hline & & $\mathrm{P}$ & - & - \\
\hline
\end{tabular}




\begin{tabular}{|c|c|c|c|c|}
\hline S.N. & Taxa & Station & $\begin{array}{c}\text { Distribution } \\
1\end{array}$ & $\begin{array}{c}\text { Sites } \\
2\end{array}$ \\
\hline & Family: Limnephilidae & & & \\
\hline & Family: Nemouridae & & & \\
\hline \multirow[t]{2}{*}{30.} & Nemoura Pictet & $\mathrm{R}$ & + & - \\
\hline & & $\mathrm{P}$ & + & - \\
\hline \multirow[t]{4}{*}{31.} & Protonemura sp. & $\mathrm{R}$ & + & - \\
\hline & & $\mathrm{P}$ & + & - \\
\hline & Order: Coleoptera & & & \\
\hline & Family: Psephenidae & & & \\
\hline \multirow[t]{2}{*}{32.} & Psephenus Haldeman & $\mathrm{R}$ & + & + \\
\hline & & $\mathrm{P}$ & + & + \\
\hline \multirow[t]{3}{*}{33.} & Ectopria Leconte & $\mathrm{R}$ & - & + \\
\hline & & $\mathrm{P}$ & - & + \\
\hline & Family: Elmidae & & & \\
\hline \multirow[t]{3}{*}{34.} & Heterlimnius Hinton & $\mathrm{R}$ & + & + \\
\hline & & $\mathrm{P}$ & + & + \\
\hline & Family: Dytiscidae & & & \\
\hline \multirow[t]{4}{*}{35.} & Dytiscus Linnaeus & $\mathrm{R}$ & - & - \\
\hline & & $\mathrm{P}$ & + & - \\
\hline & Order : Odonata & & & \\
\hline & Family: Gomphidae & & & \\
\hline \multirow[t]{2}{*}{36.} & Ophiogomphus Selys & $\mathrm{R}$ & - & - \\
\hline & & $\mathrm{P}$ & + & + \\
\hline \multirow[t]{2}{*}{37.} & Octogomphus Selys & $\mathrm{R}$ & + & - \\
\hline & & $\mathrm{P}$ & + & - \\
\hline \multirow[t]{3}{*}{38.} & Dromogomphus Selys & $\mathrm{R}$ & - & - \\
\hline & & $\mathrm{P}$ & + & - \\
\hline & Family: Agrionidae & & & \\
\hline \multirow[t]{2}{*}{39.} & Argia Rambur & $\mathrm{R}$ & + & - \\
\hline & & $\mathrm{P}$ & + & - \\
\hline \multirow[t]{4}{*}{40.} & Sympetrum Newman & $\mathrm{R}$ & - & - \\
\hline & & $\mathrm{P}$ & + & - \\
\hline & Order : Hemiptera & & & \\
\hline & Family: Corixidae & & & \\
\hline \multirow[t]{4}{*}{41.} & Corixa sp. & $\mathrm{R}$ & - & - \\
\hline & & $\mathrm{P}$ & + & - \\
\hline & Order: Neuroptera & & & \\
\hline & Family: Corydalidae & & & \\
\hline \multirow[t]{4}{*}{42.} & Corydalis Latreille & $\mathrm{R}$ & + & + \\
\hline & & $\mathrm{P}$ & - & + \\
\hline & Order: Tricladida & & & \\
\hline & Family: Planaridae & & & \\
\hline \multirow[t]{2}{*}{43.} & Planaria Girard & $\mathrm{R}$ & + & + \\
\hline & & $\mathrm{P}$ & + & + \\
\hline
\end{tabular}




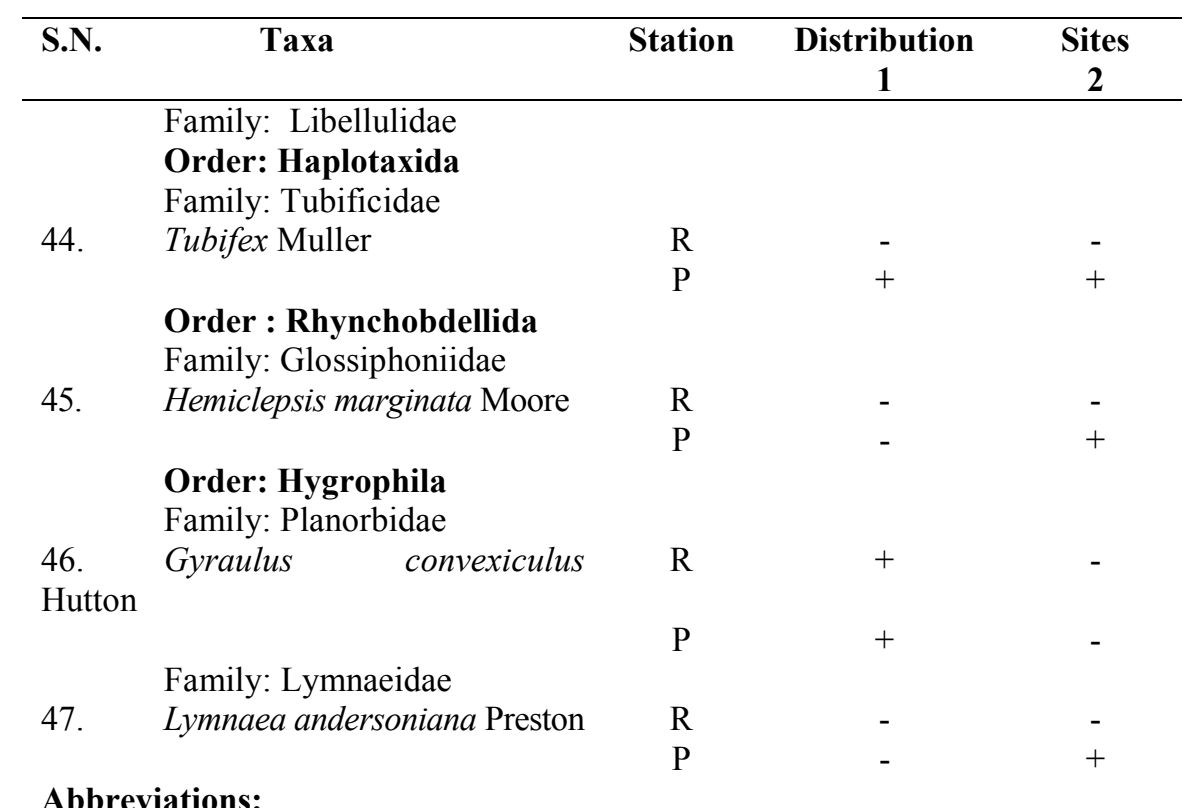

$\mathrm{R}=$ Riffle, $\mathrm{P}=$ Pool, 1 = Mardi khola, $2=$ Vijayapur khola, $(+)=$ Present and $(-)=$ Absent 


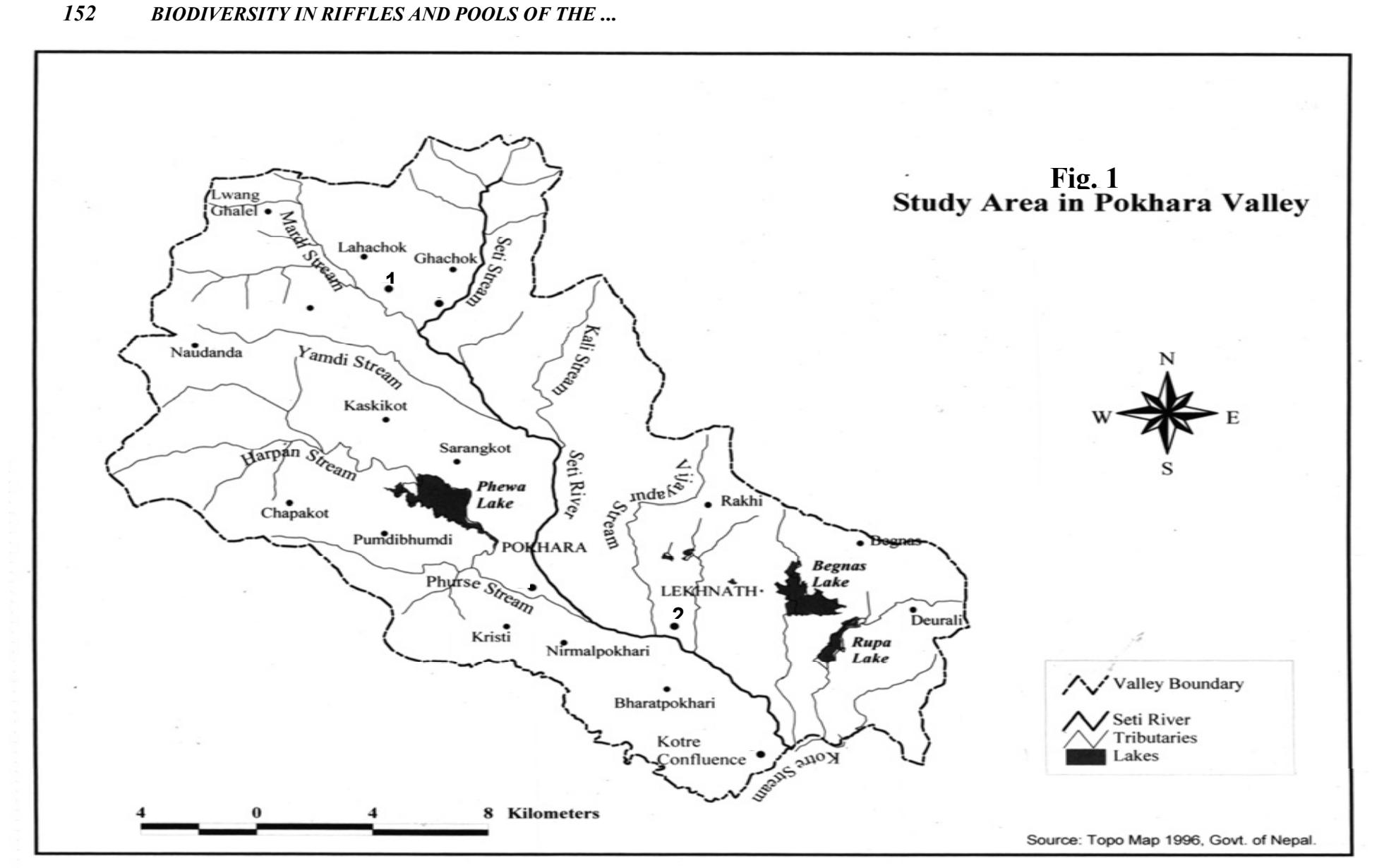

